症例

集学的治療により再発後20力月無増悪の直腸内分泌細胞癌の 1 例

群馬大学大学院蔵器病態外科学, 前橋赤十字病院消化器病センター*, 同 病理部**

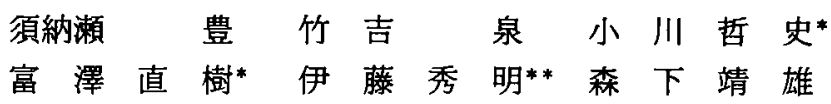

患者は48歳, 男性で, 便通異常と肛門痛で近医を受診し, 直腸腫瘤として紹介された。 CF で直腸に巨大な粘膜下腫瘍を認め, CT と MRI で, 骨盤壁浸潤を伴う $12 \mathrm{~cm}$ 大の腫瘤

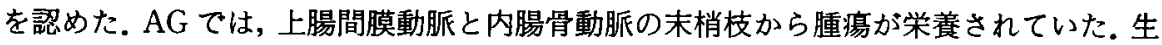
検より，内分泌細胞癌と診断して腹会陰式直腸切断術を施行した。摘出標本では，中心 部壊死を伴う充実性腫汮で, 梨状筋浸潤を認めた. 組織学的には核密度の高い類円形腫 瘍細胞がびまん性に増殖し，内腸骨動脈領域のリンパ節転移があった，免疫染色では NSE, CD56が陽性であった。術後 4 カ月で骨盤内再発と肝転移をきたし，局所に放射線 照射, 肝に TACE を行い, CDDP と CPT-11，および L-OHP を始めとする全身化学療 法を行った．間もなく腫瘍が縮小し，再発後20力月無増悪で経過中である．巨大な内分 泌細胞癌の再発に対し集学的治療を行い, 縮小後長期間無増悪で経過中の症例を経験し たので報告する。

索引用語：直腸, 内分泌細胞癌, 集学的治療

はじめに

内分泌細胞癌は消化管に発症することは稀で, 食道 が0.05 2.4\%, 胃が0.1\%, 大腸が0.2\%と報告されて いる゙. また, 全大腸癌の $0.2 〜 1 \%$ を占めるにすぎ ず2)，本邦での報告は60例程度である。.また，早期に転 移する傾向が強く, 予後は極めて不良である. 今回, 骨盤内を占拠した巨大な内分泌細胞癌を切除し, 術後 再発に対して集学的治療を行い再発後20力月無増悪で 経過中の症例を経験したので報告する.

$$
\text { 症例 }
$$

患者：48歳, 男性.

主訴：排便困難, 肛門部痛.

既往歴：特記すべきことなし。

現病歴：平成16年 1 月より排便困難，同年 2 月ょり 肛門部痛を生じていた. 3 月に近医受診し, 直腸診て 巨大腫瘤を指摘され紹介された。

入院時現症：全身状態は良好, 腹部は平坦, 軟で, 体表リンパ節も触知しなかった。直腸診では, 肛門縁

2006年 4 月18日受付 2006 年 5 月 26 日採用 〈所属施設住所〉

干371-8511 前橋市昭和町 3-39-22
より約 $2 \mathrm{~cm}$ 口側の直腸後壁に弾性硬の巨大な腫痛を 触知した。

血液・生化学検査所見：異常值を示すものはなく， CEA, CA19-9, NSE 等の腫瘍マーカーも正常範囲内 であった.

大腸内視鏡所見：直腸後壁を中心に内腔を圧排狭小 化する巨大な腫瘤を認めた。大部分は正常粘膜に覆わ れ，中心に腤窝を形成していた。その際，採取した生 検組織診（HE・免疫染色）上り直腸内份泌細胞癌と診 断された.

腹部 CT 所見：不均一に造影され，骨盤腔を占拠す る径 $12 \mathrm{~cm}$ 大の腫瘤を認めた（図 1 )。

腹部 MRI 所見：膀胱から前立腺の高さに及ふ内部 不均一な腫瘤を認めた。周囲組織の不整な低信号化を 伴い，浸潤が疑われた（図 2 ).

以上の所見より骨盤壁浸潤を伴った直腸内分泌細胞 癌と診断し，平成16年 4 月に手術を施行した。

手術所見：肝転移や腹膜播種はなかった，腫場は骨 盤底と強固に瘜着し, 右後方で梨状筋に浸潤していた。 膀腅や前立腺との剩離は可能で，側方リンパ節郭清を 伴う腹会陰式直腸切断術 D3を施行した。術中所見は大 腸癌取扱い規約第 6 版に準じると Ai（梨状筋）N2 P0 

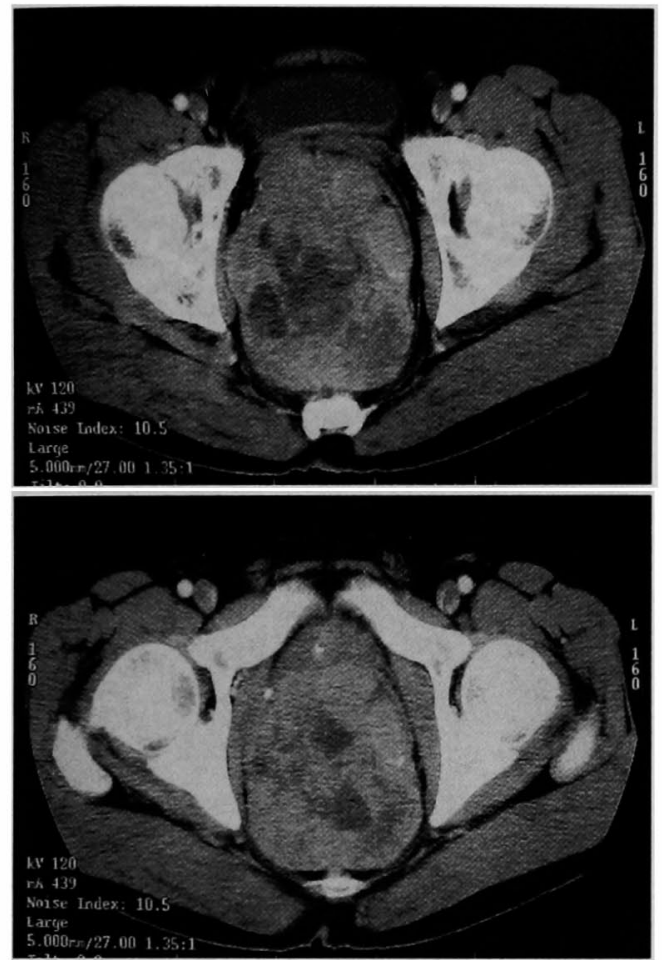

図 1 腹部 CT：不均一に造影され，骨盤䏶を占拠す る径 $12 \mathrm{~cm}$ 大の腫瘤を䜑めた。

H0 M0 Stage III b であった.

摘出標本所見：腫場は直腸粘膜樑層上り墏膜側に発 育していた。充実生で中心壊死を伴い $12 \times 10 \times 8.5 \mathrm{~cm}$ 大の腫瘤を形成していた。一部で梨状筋に浸潤してい た(図3).

病理組織学的所見：小型裸核状で核密度の高い類円 形の腫瑝細胞がびまん性に増殖し，高度の腫瘍壊死を 伴っていた(図 4 a)）。組織学的にも梨状筋に浸潤して いた、リンパ節転移は\#262R が陽性であった。免疫染 色では NSE とCD56が陽性で(図 4 b，c），chromo. granin A と synaptophysin は陰性であった。

術後経過：術後 1 カ月で退院したが，同年 8 月に下 肢のしびれを生じ，CTで骨盤内局所再発と多発性肝 転移と診断した(図 5 )。 また，両側の水堅症をきたし ていたため尿管ステントを挿入し，骨盤内照射 (LinacX 線2Gy $\times 25$ 回) と transcatheter arterial chemoembolization (TACE) (epirubicin $30 \mathrm{mg} / \mathrm{m}^{2}$, lipiodol $6 \mathrm{ml}$, gelatin sponge) を行った.

化学療法：同年 9 月よりCDDP+CPT-11 (CDDP： $40 \mathrm{mg} / \mathrm{m}^{2}$ day $1 \cdot 15$, CPT $-11: 80 \mathrm{mg} / \mathrm{m}^{2}$ day $1 \cdot 15,35$

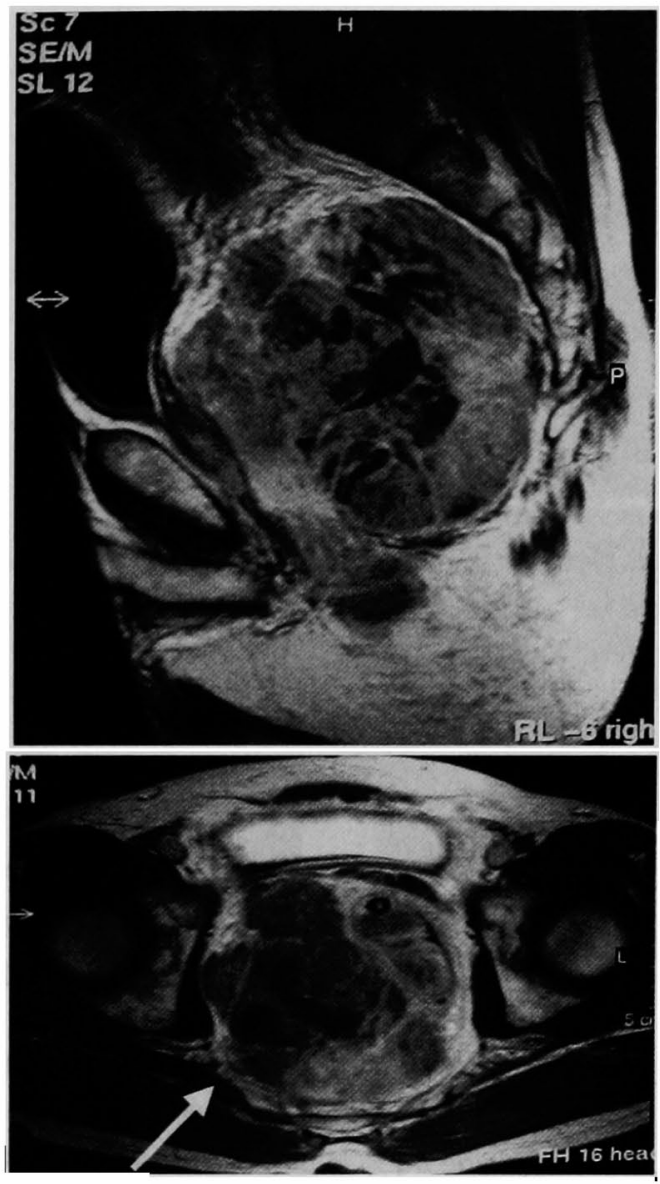

図 2 腹部 MRI : 膀胱から前立腺の高さに及ぶ内部 不均一な腫瘤を認めた. 周囲の不整な低信号化を伴 い(知印)，浸潤が疑われた。

-day cycle）による化学療法を開始した。初期に腫瘍 が縮小したが，その後不変となり，6クール施行後に Grade 3/4の白血球/血小板減少のため治療を中断し た. 平成17年 6 月より CPT-11+1-LV+5-FU (IFL 療 法）による化学療法に变更し，3クール行った．腫瘍 は著明に縮小したが, Grade 3 の悪心・嘔吐を生じ本 人の希望で中断となった。現在 $\mathrm{L}-\mathrm{OHP}+\mathrm{l}-\mathrm{LV}+5$ FU (FOLFOX-4療法)による化学療法を行っている. 腫場は縮小後に無増悪のままコントロールされている (図6).

\section{考察}

消化管の内分泌細胞腫掦は発育が緩徐で比較的悪性 度が低い古典的カルチノイドと，発育が急速で早期に 血行性・リンパ行性転移を来す内分泌細胞癌に大別さ

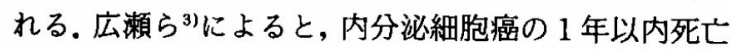




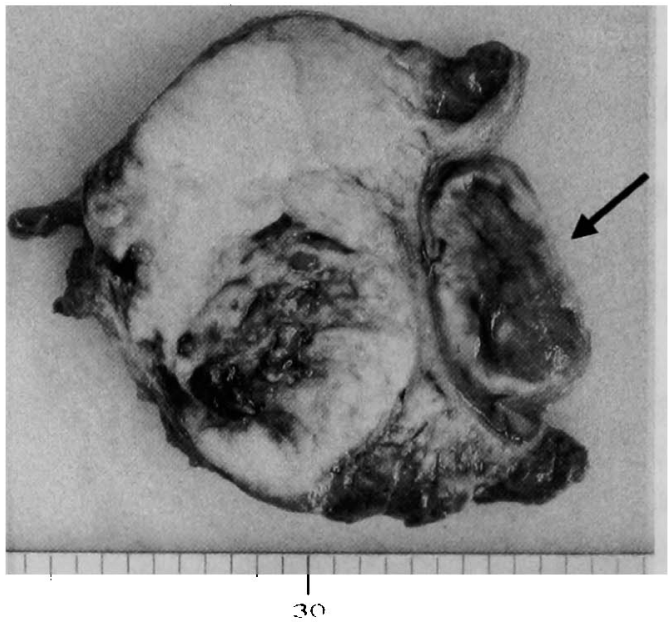

図 3 摘出標本：粘膜梁層より整膜側に発育した $12 \times 10 \times 8.5 \mathrm{~cm}$ 大の腫瘍. 中心壊死の他, 粘膜面に 乫出する成分も伴っていた (知).

率が63\%，3 年生存率が $7 \%$ \%ある。また，大塚ら 21 は 2 年以内死亡率が $81 \%$ と報告している．内分泌細胞癌 は有効な治療法が確立されておらず，特に再発症例の 予後は不良で, 多くの場合 1 年以内に癌死に至る。

治療法としては外科的切除の他に化学療法が有用と の報告もあり，肺の小細胞癌に準じて欧米では CDDP+etoposide が, 本邦では CDDP+CPT-11が用 いられている．その奏効率は前者が $68 \%$ と後者が $84 \%$ であるが, 生存期間中央值は各々 9.4 力と 12.8 力月 で)，長期生存に結びついていないのが現状である.

大腸癌では，一般的には CPT-11+1-LV+5-FU を 用いた IFL，FOLFIRI 療法, L-OHP+1-LV + 5-FU を用いた FOLFOX 療法等が行われ，奏効率が39〜56 $\%$, 生存期間が14.8 21.5力月と高い有効性が報告さ れるようになってきた5). 本症例では, 初めに肝転移に 対してTACE を, 局所再発には放射線療法を行った。 続いて全身療法として CDDP+CPT-11, IFL 療法, さ らには FOLFOX-4療法を行った。このように病状に 応して化学療法を変更し, 集学的治療を継続し得たこ とにより, 再発後20カ月もの長期生存に縏がったと考 えられる。

放射線療法は局所療法であるため，転移性あるいは 再発性病変に対する第一選択とならないことが多い。 本症例でも，血行性転移が併存するため必ずしも生命 予後の改善に寄与しないと思われたが，骨盤壁浸潤に 伴う疼痛が強い上に,水腎症もきたしていたことから，

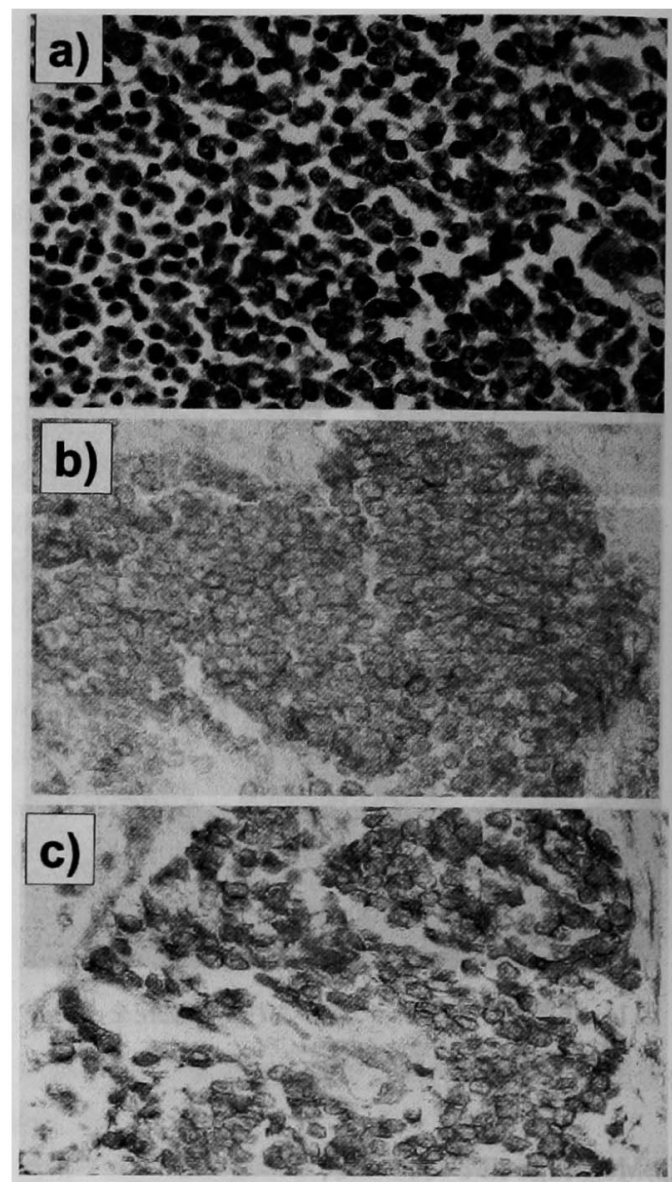

图 4 病理組織：a） HE 染色 $\times 400$, 小型裸核状て核 密度の高い類円形の腫湟細胞がびまん性に增殖. b ) NSE 染色 $\times 400$, 陽性. c) CD56染色 $\times 400$, 陽性.

局所制御も重要と考え放射線療法を行った，実際，照 射後に再発性腫瘤が著明に縮小儿，疼痛が著明に改善 したことから，放射線療法は有効であったと考えられ る.

内分泌細胞癌は，抗癌剂に対する反応が不良なため， 肝に対する局所療法としてTACE が行われることも 多い.内分泌細胞癌の肝転移は動脈血流に富み, 塞栓 による効果は高く33〜80\%とされる 率が高いものの, 生存期間の延長には結びつかないと する考元も多く，一定の見解を得ていない，本症例て は肝転移が多発性で大きく，予後規定因子になり得る と考えたため，まず TACE を行い充分な局所制御をし た上で，全身化学療法を併用した， Roche ら゙も，肝外 病変を合併した転移性内分泌腫場で, TACEに全身化 学療法を併用することの重要性を唱え，5年生存率が 

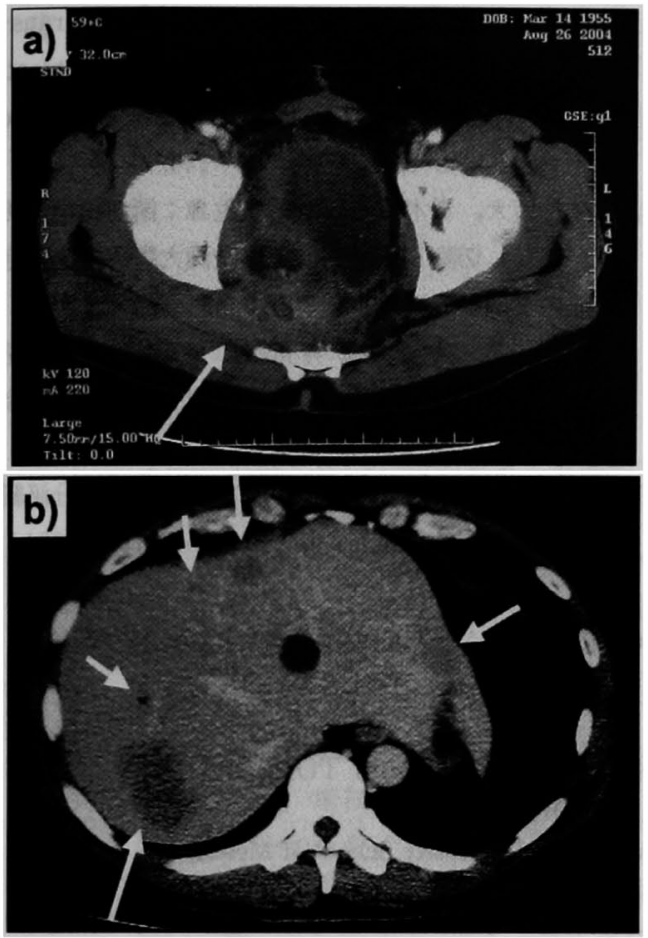

図 5 再発後腹部 CT：a）右梨状筋の周囲に骨盤内 局所再発を認めた（矢印，， b ) 両葉に多発性肝転 移を認めた（矢印）。

$83 \%$ 良好な成績を報告している．

内分泌細胞癌は，HE染色では低分化腺癌あるいは 末分化癌と類似した組織像を呈し，その鑑別は困難と される. 大塚ら ${ }^{2}$ は $\mathrm{HE}$ 染色で大腸の未分化癌と診断 された症例の約半数，低・未分化癌と診断された症例 の約 $10 \%$ が内分泌細胞癌であったと報告している，内 分泌細胞癌は特異的所見やマーカー等がなく, 組織所 見で診断される.すなわち, grimerius, chromogranin A, synaptophysin, NSE, CD56等の好銀性あるいは 免疫染色を行うか, 電子顕微鏡で内分泌顆粒を証明す る.本症例では, 術前の生検標本を免疫染色して NSE, CD56が陽性のため内分泌細胞癌と診断した。

内分泌細胞癌の予後は不良なため, 術前に診断され た場合は術前補助化学療法の有効性を示す報告がみら れる ${ }^{8)}$. 本症例も早期に肝転移再発をきたしたことを 考えると, 微少転移を制御するために術前化学療法を, 局所再発をきたしたことを考えると，病変を縮小させ 治㾏切除率を高めるために術前放射線化学療法も考慮 すべきであったのかもしれない.しかしながら，根治 手術を行っても $75 \%$ は癌死したとの報告 ${ }^{9}$ や, 術後生
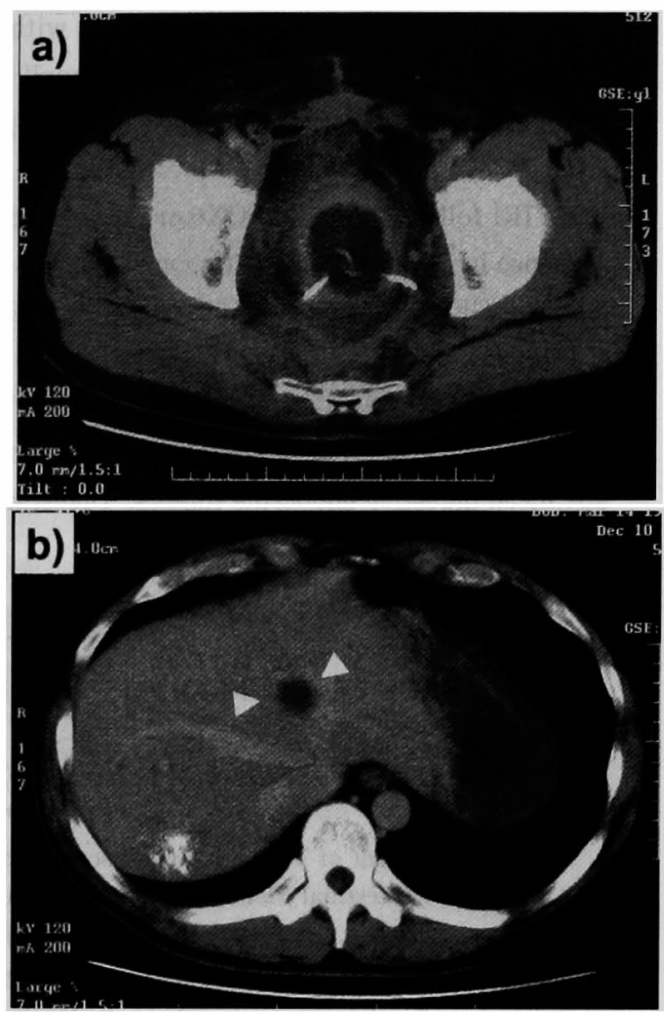

図 6 治療後腹部 CT：a）骨盤内局所再発は僅かな 壁肥厚のみとなった（両側の尿管内にはステントが 写っている)。 b ) 肝転移は縮小・消失し，S4の萑胞 のみが残存した（矢頭）。

存期間の平均值が7.2力月との報告 ${ }^{10)}$ と比較すると, 本 症例の予後は良好であり, 術後 2 年間という充分な生 存期間が得られている。

比較的稀な直腸内分泌細胞癌の切除後再発症例に対 して, 集学的治療により長期間無増悪のまま経過して いる症例を経験した。

\section{文献}

1) Remic SC:Extrapulmonary small cell carcinoma : A review of the literature with emphasis on therapy and outcome. Medicine $66: 457$ $-471,1987$

2）大塚正彦, 加藤 洋 : 大腸の低・未分化癌の臨床 病理学的検討：分類および内分泌細胞癌との関連 について. 日消外会誌 $25: 1248-1256,1997$

3）広瀬邦弘, 篠原敏樹, 佐治 裕: 直腸原発内分泌 細胞癌の 1 例. 日臨外会誌 $65: 1620-1624,2004$

4) Noda K, Nishiwaki Y, Kawahara M, et al: 
Irinotecan plus cisplatin compared with etoposide plus cisplatin for extensive smalicell lung cancer. New Engl J Med $346: 85-91$, 2002

5) FOLFIRI followed by FOLFOX6 or the reverse sequence in advanced colorectal cancer : A randomized GERCOR study. J Clin Oncol $22: 229$ $-237,2004$

6) Ruszniewski P, Malka D: Hepatic arterial chemoembolization in the management of advanced digestive endocrine tumors. Digestin $62: 79-83,2000$
7) Roche A, Girish BV, Baere T, et al: Transarterial chemoembolization as first-line treatment for hepatic metastasis from endocrine tumors. Eur Radiol 13:136-140, 2003

8）津谷康大, 青木秀樹, 原野雅生他: 街前化学療法 が著効し切除し得た十二指腸浸潤大腸内分泌細胞 癌の 1 例. 日消外会誌 $37: 1485-1490,2004$

9）杉浦 博, 高橋 弘, 下沢英二他：直腸の内分泌 細胞癌, 高分化型腺癌の重複例の 1 例. 日臨外会 誌 $63: 1040-1044,2002$

10）山内希美, 宮田知幸, 岡田将直 他：直腸内分泌細 胞癌の 1 例. 日臨外会誌 $65: 751-755,2004$

\title{
A GIANT ENDOCRINE CELL CANCER OF THE RECTUM THAT REMAINED PROGRESSION FREE FOR 20 MONTHS WITH MULTIDISCIPLINARY TREATMENT
}

\author{
Yutaka SUNOSE, Izumi TAKEYOSHI, Tetsushi OGAWA*, Naoki TOMIZAWA*, \\ Hideaki ITOH** and Yasuo MORISHITA \\ Department of Thoracic and Visceral Organ Surgery, Gunma University School of Medicine \\ Gastro-intestinal Medical Center* and Pathology Department**, Maebashi Red Cross Hospital
}

We report a recurrent case of giant endocrine cell eancer (ECC) of the rectum that remained progression free for 20 months with multidisciplinary treatment. A 48-year-old man visited our hospital because of incontinence and anal pain. Colonoscopy showed a giant submucosal tumor with central ulceration in the rectum. CT and MRI revealed a heterogeneous mass in the pelvic space, which measured $12 \mathrm{~cm}$ and invaded the pelvic wall. Angiography showed that it was supplied from the superior mesenteric and internal iliac arteries. The tumor was diagnosed from a biopsy as ECC and the patient underwent radical abdominoperineal resection. The resected specimen showed hemorrhagic necrosis in the center of the tumor invading the piriform muscle with lymph node metastas. Immunohistochemical staining detected NSE and CD56. Four months after the surgery, local recurrence and liver metastasis were seen, and radiation and transcatheter arterial chemoembolization were performed. Systemic chemotherapy with CDDP, CPT-11, and L-OHP followed. The tumor soon diminished, and the patient has remained progression free for 20 months. 